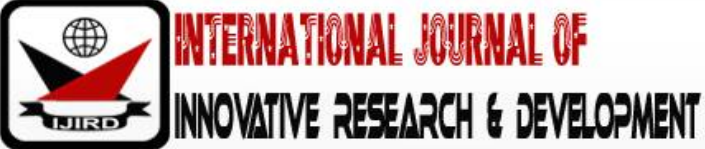

ISSN 2278 - 0211 (Online)

\section{Production of Ceiling Board Using Bio Composite Of Ground Nut Shell and Palm Karnel Husk with Starch as Binding Resin}

\begin{tabular}{|c|}
\hline Ameh A. Achadu \\
Student, Department of Industrial Technical Education, University of Nigeria Nsukka, Nigeria \\
Dung Choji Joseph \\
Assistant Lecturer, Department of Science and Technology Education, University of Jos, Nigeria \\
Edmond O. Anaele \\
Professor, Department of Industrial Technical Education, University of Nigeria Nsukka, Nigeria
\end{tabular}

\begin{abstract}
:
This study was carried out to seek process parameter for the production of bio-composite Ceiling Board. This is done with a view to having alternative materials to the conventional ceiling boards that are costly and also pose health risks, reducing the cost of building material by utilizing agro- waste with disposal problems. Eight specific objectives were raised. Eight research questions were formulated to guide the study. The study employed Research and Development (R\&D) design. Twenty-four (24) bio composite ceiling board samples were produced in different mixing ratio and tested for their properties. The test result are: Modulus of elasticity $5600 \mathrm{~N} / \mathrm{mm}$, modulus of rupture $0.49 \mathrm{~N} / \mathrm{m}^{2}$ compressive strength $760 \mathrm{KPA}$, density $385 \mathrm{~kg} / \mathrm{m}^{3}$, thermal conductivity $0.37 \mathrm{kw} / \mathrm{mk}$, resistivity $1.28 \mathrm{mk} / \mathrm{w}$, water absorption $35.5 \%$ and Fire resistance in accordance with ASTM standards The findings revealed that the mix ratio GNS $0.040 \mathrm{~kg}:$ PKH $0.060 \mathrm{~kg}$ : starch $0.030 \mathrm{~kg}$ satisfied all the parameters that were tasted and therefore has the potentials to be adopted for the production of bio-composite ceiling board. Other mix ratios were deficient in one parameter or the other. Based on the findings, cottage industries that would utilize these agricultural wastes should be built in areas where these wastes are found.
\end{abstract}

Keywords: Ceiling boards, bio-composite, natural Fibre, production, agro waste

\section{Introduction}

The demand for wood products has been increasing with the increasing in the population of the world that adversely influences the sustainable utilization of forest resources into building elements. Bachman (2008) mentioned some essential elements of shelter or building which include Doors, Windows, Roofs, Walls, Ceilings among others. A ceiling board is a horizontal slab between the headroom and the roof terraces. Obam (2016). Opined that it is generally not a structural element but a shell concealing the details of the structure above. According to Madu, Nwankwojike \& Ani (2018) ceilings are panel sheets covering the upper layer of an internal section of a building which improves its aesthetics and reduces sound and heat transmission in the house, it is an essential part in the building process which plays a key role in the thermal comfort of a building. (Ataguba, 2016). Ceiling as one of the main building elements is very important and has the main function of thermal Conductivity and thermal Resistivity which reduces or increases excessive heat in the room, Water Absorption which is the ability of the ceiling board to retain moisture in the pore or voids without releasing it and without swelled out which is called dimensional stability, Modulus of Rupture or flexural strength which is the measure of resistance to fracture or deformation under load. Modulus of elasticity, it is the tendency of an object to deform along an axis when opposing forces are applied along that axis. Compressive Strength, this is the capacity of the ceiling material to withstand loads. Density, is the relationship between the mass of the substance and how much space it takes. Fire Resistance, is the ability of the ceiling board to delay fire escalation and fire burning. There are different types of ceiling boards. These include: gypsum ceiling boards, acoustical ceiling boards, gypsum fibre ceiling boards and cement fibre ceiling boards etc. These types of ceiling boards are grouped in accordance to the raw materials used for the production (Ajayi and Fuwape, 2005). Gypsum ceiling boards are produced from gypsum, Acoustical ceiling boards are obtained from mineral wool, gypsum, small amount of paper and starch.

Adinarayana (2015) confirmed that effective performance of ceiling in building depends on the types of material. Material is a mixture of substance that constitute an object from which a thing is made. According to Sandrers (2011), material is generally believed to be anything used to make something. It could be raw (natural) or processed types. Seeley (2010) explained further that, the common materials used for ceiling boards are asbestos, wood, polyvinyl chloride (PVC) and plaster of Paris (POP). These materials possess different properties that include absorption of moisture and swelling, 
brittleness, fibrous and high cost. (South African Building Interior System Association SABISA, 2013). Invariably materials used in ceiling board are not expected to endanger human health in any form both during construction and while dwelling in the building. The asbestos that is used in most residential buildings in Nigeria is associated with the disease of the lungs and therefore prohibited. Asbestos ceiling boards are fragile, pose health risks and relatively costly. (Koleoso 2019)

The word 'waste' readily brings to mind any unwanted, useless item that has outlived its usefulness and needs, and usually to be disposed immediately not minding the effects of such disposal practices on the environment. Groundnut shell and palm kernel husk which are the two basic raw materials for this research work, are considered as waste materials and the commonest disposal method is incineration with its attendant effect on the environment. Isheni, Yahaya, Mbishida, Achema \& Karfe, (2017) pointed out that approximately $25-40 \%$ of municipal solid waste generated worldwide is made up of agro-waste. The waste generated from the processing of agricultural produce such as Ground nut shell and palm kernel husk are already a threat to the environment and human beings because of the disposal problem. The traditional way of disposal of this waste is by burning, which increase global warming. Accumulated wastes release offensive odour there by contributing to air pollution, these waste products can however be recycled into new products of ceiling board that are more environmentally friendly and can equally add value to the economic development of any society and the building construction industry using agro -waste composite.

Composite is any product composed of two or three different types of material that are combined to form something completely different and better. These materials are now replacing the traditional material because of its superior properties such as high strength-to-weight ratio. Natural fibre composites have become more attractive due to their specific strength and light weight. (Onkar \& Ganesh, 2016). Mantia, \& Morreale, (2011) stated that composite material is a material made from two or more constituent materials with significantly different physical or chemical properties that, when combined, produce a material with characteristics different from the individual components. Plant derived fiber are known as Bio-composites which are eco-friendly; such composites are termed as green composites. (Naidu, Sudarshan \& Hari, 2013). Bio composite (bio from Greek 'alive) is a composite material formed by a matrix (resin) and a reinforcement of natural fibers. Bio fibers are the principal components of bio composites, which are derived from biological origins, for example, fibers from crops. In the context of this study, the matrix (Resins) is the starch which serves as adhesive for the production. (Shahzad, 2012).

Production is a process by which goods and services are created Therefore, production is that which is concerned with the transformation of range of inputs into the required product/services, having the requisite quality level (Kumar \& Suresh 2008). The process involves in the production of any product include the use of suitable material(s), equipment and method. Every item that serves one purpose or the other in the society came through production process, which involve the step-by-step conversion of one form of material into another form (Koleose, 2017). Production of ceiling board simply refers to the making or manufacturing of a ceiling board using material(s). Bergman (2013) This implies that, the nature of material dictates the process/method of production. Factors to be considered in the production process include production material(s), method of production, and production equipment. The suitability of production material depends on the properties of such material in relation to the desired product.

The combination of ground nut shell and other agro waste materials like Palm Kernel Shell for production of building materials such as ceiling board will no doubt has the potential to make a significant contribution towards the provision of low-cost building material and consequently affordable housing. Therefore, the problem that this study intends to tackle, was to find ways of utilizing ground nut shell and palm kernel husk which are agro-waste into useful production of composite ceiling board using local technology, thereby converting waste to wealth and reducing the cost of housing delivery in Nigeria.

\section{Materials and Methods}

The materials that were used for this study include

The groundnut shell (GNS) samples that were used for this study were collected from dump site in Gegu Beke, Koton Karfe Local Government, Kogi State where they are in large quantities and causes disposal problem. Palm kernel husk (PKH) was sourced from oil mills in Ogugu Olamaboro Local Government of Kogi State. Adhesive (Starch resin). Cassava starch was collected from Gari (processed powdered cassava) processing factory in Idah local Government of Kogi State. The residue was dried in the sun to get the sample in powdered form. Equipment and Tools, used for this research work include Universal Testing Machine, Thermal Conductivity Testing Machine and Tinus Olsen Universal Testing Machine were used to determine the comprehensive and mechanical properties while the Bending moment apparatus was used to determine the bending strength of the ceiling board. Electronic weighing balance was used to determine the mix ratio of the materials, Hand Trowel for mixing the materials. Measuring cylinder: For measuring the volume of water that was used during the manufacturing process, Grinding machine was used for reducing the particle size of the materials, Bags or Polythene bags was used for conveying the materials to the laboratory, Cellophane was placed on the mould before the casting of the ceiling board for easy removal. Reactor, this is the container in which all the materials used for the production was added together. Stirrer, for stirring all the materials in the reactor. Roller, this is a metallic pipe (Rammer). This was used to compress the mixture in the mould and was also used to smoothen the surface of the mixture, Other equipment used include Local sieve, cylindrical plastic container, mortar and pestle. meter rule, Vernier caliper. A wooden mould constructed by the researcher was used for casting the ceiling board as shown in Figure 1. 


\section{Results}

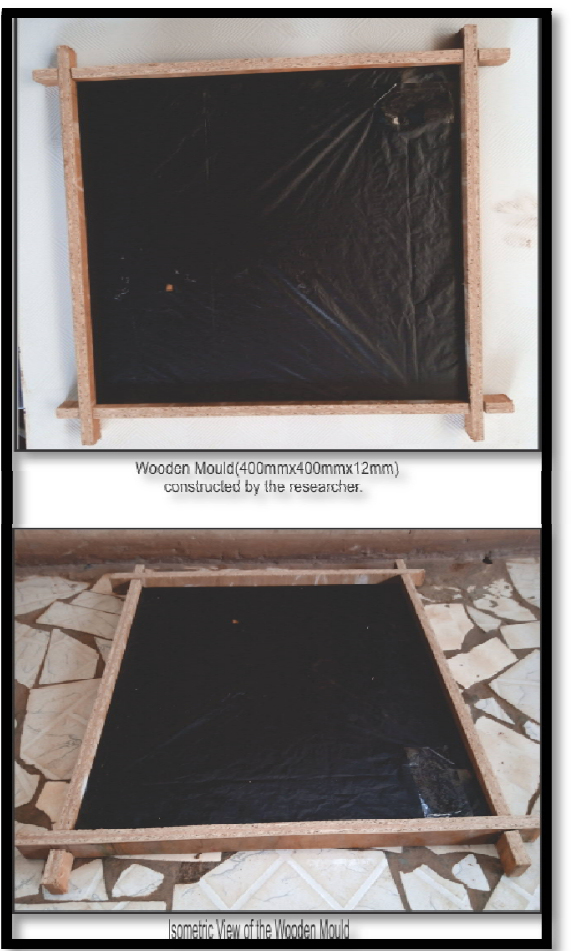

Figure 1: 400x400by12mm Wooden Mould

\begin{tabular}{|c|c|c|c|}
\hline Property & Result & ASTM Standard & Standard Remark \\
\hline Modulus of Elasticity (MOE) & $4950 \mathrm{Nmm}^{2}$ & $5000-6000 \mathrm{Nm}^{2}$ & Adequate \\
\hline Modulus of Rupture (MOR) & $0.03 \mathrm{~N} / \mathrm{m}^{2}$ & $0.03-0.07 \mathrm{~N} / \mathrm{m}^{2}$ & Good \\
\hline Compressive strength (CS) & $260 \mathrm{KPA}$ & $448-868 \mathrm{KPA}$ & Poor \\
\hline Density (D) & $349 \mathrm{~kg} / \mathrm{m}^{3}$ & $350-400 \mathrm{~kg} / \mathrm{m}^{3}$ & Adequate \\
\hline Thermal Conductivity (TC) & $0.024 \mathrm{Kw} / \mathrm{MK}$ & $0.025-0.057 \mathrm{Kw} / \mathrm{MK}$ & Adequate \\
\hline Thermal Resistivity (TR) & $0.18 \mathrm{MK} / \mathrm{W}$ & $17.5-19 \mathrm{MK} / \mathrm{W}$ & Good \\
\hline Water absorption (WA) & $0.10 \%$ & $0.37-0.64 \%$ & Poor \\
\hline Fire resistance (FR) & $=$ & $=$ & $=$ \\
\hline
\end{tabular}

Table 1: The Result of Modulus of Elasticity

\begin{tabular}{|c|c|c|c|}
\hline Property & Result & ASTM Standard & Standard Remark \\
\hline Modulus of Elasticity (MOE) & $3965 \mathrm{Nmm}^{2}$ & $5000-6000 \mathrm{Nm}^{2}$ & Poor \\
\hline Modulus of Rupture (MOR) & $0.02 \mathrm{~N} / \mathrm{m}^{2}$ & $0.03-0.07 \mathrm{~N} / \mathrm{m}^{2}$ & Poor \\
\hline Compressive strength (CS) & $370 \mathrm{KPA}$ & $448-868 \mathrm{KPA}$ & Poor \\
\hline Density (D) & $349 \mathrm{~kg} / \mathrm{m}^{3}$ & $350-400 \mathrm{~kg} / \mathrm{m}^{3}$ & Adequate \\
\hline Thermal Conductivity (TC) & $0.024 \mathrm{Kw} / \mathrm{MK}$ & $0.025-0.057 \mathrm{Kw} / \mathrm{MK}$ & Adequate \\
\hline Thermal Resistivity (TR) & $0.16 \mathrm{MK} / \mathrm{W}$ & $17.5-19 \mathrm{MK} / \mathrm{W}$ & Adequate \\
\hline Fire resistance (FR) & $=$ & $=$ & $=$ \\
\hline
\end{tabular}

Table 2: The Result of Modulus of Rupture

\begin{tabular}{|c|c|c|c|}
\hline Property & Result & ASTM Standard & Standard Remark \\
\hline Modulus of Elasticity (MOE) & $5100 \mathrm{Nmm}^{2}$ & $5000-6000 \mathrm{Nm}^{2}$ & Adequate \\
\hline Modulus of Rupture (MOR) & $0.03 \mathrm{~N} / \mathrm{m}^{2}$ & $0.03-0.07 \mathrm{~N} / \mathrm{m}^{2}$ & Good \\
\hline Compressive strength (CS) & $580 \mathrm{KPA}$ & $448-868 \mathrm{KPA}$ & Good \\
\hline Density (D) & $369 \mathrm{~kg} / \mathrm{m}^{3}$ & $350-400 \mathrm{~kg} / \mathrm{m}^{3}$ & Good \\
\hline Thermal Conductivity (TC) & $0.24 \mathrm{w} / \mathrm{mmk}$ & $0.025-0.057 \mathrm{w} / \mathrm{mmk}$ & Adequate \\
\hline Thermal Resistivity (TR) & $17.23 \mathrm{MK} / \mathrm{W}$ & $17.5-19 \mathrm{MK} / \mathrm{W}$ & Good \\
\hline Water absorption (WA) & $0.36 \%$ & $0.37-0.64 \%$ & Adequate \\
\hline Fire resistance (FR) & $=$ & $=$ & $=$ \\
\hline
\end{tabular}

Table 3: The Result of Optimal Compressive Strength 


\begin{tabular}{|c|c|c|c|}
\hline Property & Result & ASTM Standard & Standard Remark \\
\hline Modulus of Elasticity (MOE) & $5600 \mathrm{Nmm}^{2}$ & $5000-6000 \mathrm{Nmm}^{2}$ & Good \\
\hline Modulus of Rupture (MOR) & $04 \mathrm{~N} / \mathrm{m}^{2}$ & $0.03-0.07 \mathrm{~N} / \mathrm{m}^{2}$ & Good \\
\hline Compressive strength (CS) & $760 \mathrm{KPA}$ & $448-868 \mathrm{KPA}$ & Excellent \\
\hline Density (D) & $385 \mathrm{~kg} / \mathrm{m}^{3}$ & $350-400 \mathrm{~kg} / \mathrm{m}^{3}$ & Good \\
\hline Thermal Conductivity (TC) & $0.35 \mathrm{KW} / \mathrm{MK}$ & $0.025-0.057 \mathrm{Kw} / \mathrm{MK}$ & Good \\
\hline Thermal Resistivity (TR) & $18.0 \mathrm{MK} / \mathrm{W}$ & $17.5-19 \mathrm{MK} / \mathrm{W}$ & Good \\
\hline Water absorption (WA) & $0.40 \%$ & $0.37-0.64 \%$ & $=$ \\
\hline Fire resistance (FR) & $=$ & $=$ & . \\
\hline
\end{tabular}

Table 4: The Result of Density

\begin{tabular}{|c|c|c|c|}
\hline Property & Result & ASTM Standard & Standard Remark \\
\hline Modulus of Elasticity (MOE) & $4950 \mathrm{Nm}^{2}$ & $5000-6000 \mathrm{Nm}^{2}$ & Adequate \\
\hline Modulus of Rupture (MOR) & $0.3 \mathrm{~N} / \mathrm{m}^{2}$ & $0.03-0.07 \mathrm{~N} / \mathrm{m}^{2}$ & Good \\
\hline Compressive strength (CS) & $610 \mathrm{KPA}$ & $448-868 \mathrm{KPA}$ & Good \\
\hline Density (D) & $450 \mathrm{~kg} / \mathrm{m}^{3}$ & $350-400 \mathrm{~kg} / \mathrm{m}^{3}$ & Good \\
\hline Thermal Conductivity (TC) & $0.036 \mathrm{Kw} / \mathrm{MK}$ & $0.025-0.057 \mathrm{Kw} / \mathrm{MK}$ & Good \\
\hline Thermal Resistivity (TR) & $18.5 \mathrm{MK} / \mathrm{W}$ & $17.5-19 \mathrm{MK} / \mathrm{W}$ & Good \\
\hline Water absorption (WA) & $0.20 \%$ & $0.37-0.64 \%$ & Poor \\
\hline Fire resistance (FR) & $=$ & $=$ & $=$ \\
\hline
\end{tabular}

Table 5: The Result of Thermal Conductivity

\begin{tabular}{|c|c|c|c|}
\hline Property & Result & ASTM Standard & Standard Remark \\
\hline Modulus of Elasticity (MOE) & $4950 \mathrm{Nmm}^{2}$ & $5000-6000 \mathrm{Nm}^{2}$ & Adequate \\
\hline Modulus of Rupture (MOR) & $0.3 \mathrm{~N} / \mathrm{m}^{2}$ & $0.03-0.07 \mathrm{~N} / \mathrm{m}^{2}$ & Good \\
\hline Compressive strength (CS) & $580 \mathrm{KPA}$ & $448-868 \mathrm{KPA}$ & Good \\
\hline Density (D) & $450 \mathrm{~g} / \mathrm{m}^{3}$ & $350-400 \mathrm{~kg} / \mathrm{m}^{3}$ & Good \\
\hline Thermal Conductivity (TC) & $0.24 \mathrm{Kw} / \mathrm{MK}$ & $0.025-0.057 \mathrm{Kw} / \mathrm{MK}$ & Adequate \\
\hline Thermal Resistivity (TR) & $16.8 \mathrm{MK} / \mathrm{W}$ & $17.5-19 \mathrm{MK} / \mathrm{W}$ & Adequate \\
\hline Water absorption (WA) & $0.40 .3 \%$ & $0.37-0.64 \%$ & Good \\
\hline Fire resistance (FR) & $=$ & $=$ & $=$ \\
\hline
\end{tabular}

Table 6: The Result of Thermal Resistivity

\begin{tabular}{|c|c|c|c|}
\hline Property & Result & ASTM Standard & Standard Remark \\
\hline Modulus of Elasticity (MOE) & $4950 \mathrm{Nmm}^{2}$ & $5000-6000 \mathrm{Nmm}$ & Adequate \\
\hline Modulus of Rupture (MOR) & $0.3 \mathrm{~N} / \mathrm{m}^{2}$ & $0.03-0.07 \mathrm{~N} / \mathrm{m}^{2}$ & Good \\
\hline Compressive strength (CS) & $300 \mathrm{KPA}$ & $448-868 \mathrm{KPA}$ & Poor \\
\hline Density (D) & $124 \mathrm{~kg} / \mathrm{m}^{3}$ & $350-400 \mathrm{~kg} / \mathrm{m}^{3}$ & Poor \\
\hline Thermal Conductivity (TC) & $124 \mathrm{~kg} / \mathrm{m}^{3}$ & $350-400 \mathrm{~kg} / \mathrm{m}^{3}$ & Poor \\
\hline Thermal Resistivity (TR) & $16.5 \mathrm{MK} / \mathrm{W}$ & $17.5-19 \mathrm{MK} / \mathrm{W}$ & Adequate \\
\hline Water absorption (WA) & $0.10 .8 \%$ & $0.37-0.064 \%$ & Poor \\
\hline Fire resistance (FR) & $=$ & $=$ & $=$ \\
\hline
\end{tabular}

Table 7: The Result of Water Absorption

\begin{tabular}{|c|c|c|c|}
\hline Property & Result & ASTM Standard & Standard Remark \\
\hline Modulus of Elasticity (MOE) & $5312 \mathrm{Nmm}^{2}$ & $5000-6000 \mathrm{Nm}^{2}$ & Adequate \\
\hline Modulus of Rupture (MOR) & $0.2 \mathrm{~N} / \mathrm{m}^{2}$ & $0.03-0.07 \mathrm{~N} / \mathrm{m}^{2}$ & Adequate \\
\hline Compressive strength (CS) & $447 \mathrm{KPA}$ & $448-868 \mathrm{KPA}$ & Adequate \\
\hline Density (D) & $450 \mathrm{~kg} / \mathrm{m}^{3}$ & $350-400 \mathrm{~kg} / \mathrm{m}^{3}$ & Good \\
\hline Thermal Conductivity (TC) & $0.050 \mathrm{Kw} / \mathrm{MK}$ & $0.025-0.057 \mathrm{Kw} / \mathrm{MK}$ & Good \\
\hline Thermal Resistivity (TR) & $18.5 \mathrm{MK} / \mathrm{W}$ & $17.5-19 \mathrm{MK} / \mathrm{W}$ & Good \\
\hline Water absorption (WA) & $0.20 . \%$ & $0.37-0.64 \%$ & poor \\
\hline Fire resistance (FR) & $=$ & $=$ & $=$ \\
\hline
\end{tabular}

Table 8: The Result of Fire Resistance 


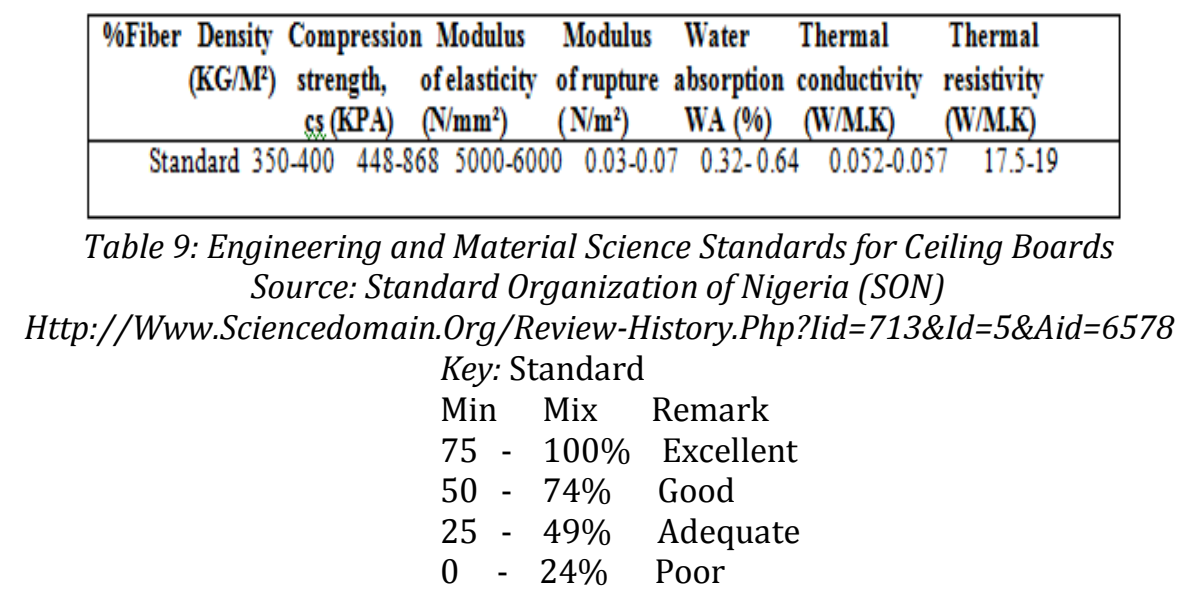

\section{Discussion}

The bio- composite ceiling board produced from the mix ratio of GNS $0.040 \mathrm{~kg}$ : PKH 0.060kg: starch $0.030 \mathrm{~kg}$ Table 4 has Modulus of elasticity of $5600 \mathrm{~N} / \mathrm{mm}^{2}$, Modulus of rupture of $0.4 \mathrm{~N} / \mathrm{mm}^{2}$ is good enough to resist deformation under load and opposing forces. This attribute does not alter the size and shape of the ceiling board, the mix ratio has excellent compressive strength of 760KPA which makes the ceiling board rigid to support fastener load sustaining the total roofing system. The density of the mix ratio also yielded good result of $385 \mathrm{Kg} / \mathrm{mm}^{2}$. This attribute makes the ceiling board well compacted and does not contain air space which is not liable to collapse or breakage during storage, transportation and usage. Good thermal conductivity of $0.35 \mathrm{kw} / \mathrm{mk}$, thermal resistivity of $18.0 \mathrm{kw} / \mathrm{mk}$ respectively this attribute of the biocomposite ceiling resist heat penetration and help provide comfort in the building. water absorption of the composite ceiling board produced from the mix ratio is $25.5 \%$ which is within the accepted standard this ceiling board has good water holding capacity. This result agrees with that of Ataguda (2016) and Obam (2012), The flexural strength of $0.03360 \mathrm{~N} / \mathrm{m}^{2}$ was obtained, which is good enough to withstand wind forces. In a study conducted by Banjo, Afolaya \& Ogunji in 2016 and Ataguda in 2016, Obam in 2012 got flexural strength of $0.054 \mathrm{~N} / \mathrm{mm}^{2}, 0.03 \mathrm{~N} / \mathrm{mm}^{2} \mathrm{and} 0.05 \mathrm{~N} / \mathrm{mm}^{2}$ respectively. The composite ceiling board from GNS: PKH: Starch as binder: has adequate flexural strength than that produced by Ataguda. However, the one produced by Banjo et al and Obam yielded more strength. The water absorption of the composite ceiling tile is $19.22 \%$ which means the composite ceiling tile is impervious; this means that it will maintain dimensional stability. Alireza, Ali \& Mehrab (2014) investigated the water absorption property of wood plastic composite and got $12 \%$ water absorption, Banjo et'al got water absorption of $49.85 \%$ while Ataguda (2016) got water absorption of $14.5 \%$. The result of Banjo et'al exceeded the specified standard therefore the ceiling board will absorb water, the thickness will swell up. The researchers, Alireza et'al (2014) and Ataguda (2016) obtained, water absorption values that are within the accepted standard as shown in Table 9. These results indicate that the composite ceiling board produced from GNS and PKH has a higher resistance to fracture than that of Obam. This mix ratio has satisfied all the physical properties investigated and therefore ideal for production of bio-composite ceiling board.

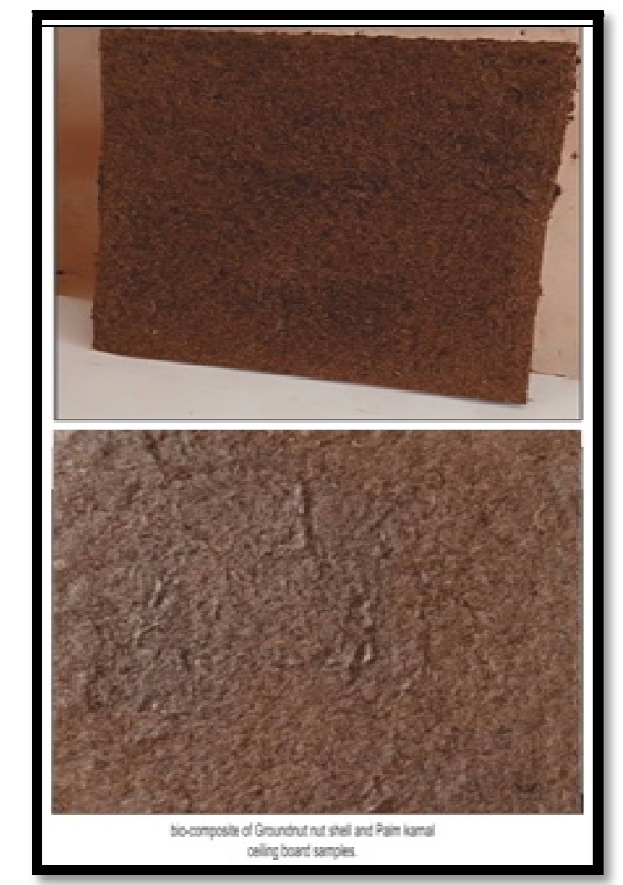

Figure: 2. Bio- composite of Groundnut Shell \& Palm Kernel Ceiling Board 


\section{Conclusion}

This study was carried out to solve the problem of high cost of building materials especially ceiling board. The study was to proffer solution to the challenge of agricultural waste disposal particularly Groundnut shell and palm kernel husk by utilizing these wastes for the production of bio-composite ceiling board. The eight different mix ratios were tested. Only one had all the properties of ceiling board within the accepted standard of ASTM. That is GNS $0.040 \mathrm{~kg}$ : PKS $0.060 \mathrm{~kg}$ : starch $0.030 \mathrm{~kg}$. The rest of the mix ratios were deficient in one property or the other. Based on the findings it is recommendations that.

\section{Recommendations}

The findings of the mix ratio that satisfy all the parameters be used by ceiling board manufacturing industries for massive production of bio-composite ceiling board. The Nigerian Building and Roads Research Institute (NBRRI) should recommend this ceiling board to Architects, prospective house owners and contractors. Production Factories for biocomposite ceiling boards be established as part of the development programmes of higher institutions creating jobs for both skilled and unskilled personnel in the midst of locally available raw materials.

\section{References}

i. Adinarayana, M. (2015) Construction and building materials Retrieved from www.vigyanprasal.gov.in> brief>building.pdf.

ii. Allen E. (2005) Fundamentals of Building materials and methods ( $5^{\text {th }}$ ed) New York. John Willey and Sons Inc.

iii. Asante-Kyei, K., 2012. Manufacturing of local plaster of Paris (P.O.P.) from salt residue mined in Sege in the Dangme East District of the Greater Accra Region of Ghana. Res. J. Environ. Earth Sci., 4: 953-958.

iv. ASTM C367/C367-09 Standard Test Method for strength properties of prefabricated architectural acoustical tile on lay in ceiling panels. 2014 ASTM International West Conshocken P.A.

v. ASTM D7433-13 Standard Test Method for Measuring Surface Water Absorption of overlaid Wood based Panels. 2013 ASTM International West Conshocken, P.A.

vi. ASTM E 119-00 (2014). Standard test methods for fire Tests of building construction and materials.

vii. ASTM international, West Conshohocen PA 2014.

viii. Ataguba, C.0. (2016), Properties of ceiling board produced from a composite of waste paper and rice husk. International journal of advanced in science engineering and technology.117-120

ix. Atiqah, A. Jawaid, M. Ishak, M \& Sapuan, M. (2017). Moisture Absorption and Thickness Swelling Behaviour of Sugar Palm Fibre Reinforced Thermoplastic Polyurethane, Procedia Engineering 184 581-586.

x. Bachman, R. \& Dowty, S. (2008). Non-structural components and none building structures, Retrieved from www.skghoshassociates,com/.../Bachman.

xi. Bart, J. C. J. (2005) Adhessive in polymers: Industrial analysis and applications England: John Wiley and Sons ltd.

xii. Beghezan, C.T., (2015), 'Fabrication and Performance of Natural Reinforced Composite Materials', Journal of Polymer Engineering and Science, 35, 970 - 978.

xiii. Bergman, T. I. \& Bourell, D. L. (2013). Material and Processing Retrieved from www.wtec.org>addditve $>$ report,pdf.

xiv. Holbery, J. \& Houston, D. (2006). Natural-fiber-reinforced polymer composites applications in automotive. Jom, 58(11): 80-86.

xv. Koch, J. D. Glassley, M. R.\& Cunnningham, R. N. (2011) Process for the mixture of ceiling Tiles Retrieved from http://www.google.com/patents/USS194206.

xvi. Koleoso A. O, Edmond O. A, Godwin K. O \& Hyginus O. O. (2019) Production of Ceiling Tile with High Density Polyethylene (HDPE) and Polyethylene Terephthalate (PET) Plastic Wastes as Main Ingredients. Retrieved from https://www.researchgate.net/publication/336811257

xvii. Madu. Nwankwojike \& Ani, (2018). Optimal Design for Rice Husk-Saw Dust Reinforced Polyester Ceiling Board'American Journal Of Engineering Research (AJER), 7, 6. 11-16.

xviii. Mantia, F. \& Morreale, M. (2011). Green composites: A brief review. Composites Part A: Applied Science and Manufacturing 42(6): 579-88, Doi: 10.1016/j.compositesa.2011.01.017.

xix. S.O. Obam (2016) 'Properties of saw dust, paper and starch composite ceiling borads'. American Journal of Scientific and Industrial Research Vol. 3 pp300- 304. Sandrers, P. (2011). Types of building materials Retrieved from htt://www.lawyerment.com/library/article/RealEstate/General/3624:html.

xx. Seeley, I.H. (2010). Building technology: fifth edition. London: Palgrave Macmillian Press Ltd

xxi. South African Building Interior System Association (SABISA) (2013) General specification for suspended ceiling. Retrieved from www.superteceiling.co.za $>2013 / 02$ 